\title{
Monitoring the escape of transgenic oilseed rape around Japanese ports and roadsides
}

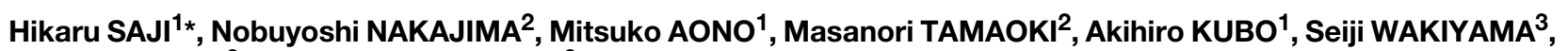 \\ Yoriko HATASE ${ }^{3}$ and Masato NAGATSU ${ }^{3}$ \\ ${ }^{1}$ Environmental Biology Division, National Institute for Environmental Studies, 16-2 Onogawa, Tsukuba, 305-8506, Japan \\ ${ }^{2}$ Biodiversity Conservation Research Project, National Institute for Environmental Studies, 16-2 Onogawa, Tsukuba, 305-8506, Japan \\ ${ }^{3}$ Japan Wildlife Research Center, 3-10-10 Shitaya, Taito-Ku, Tokyo, 110-8676, Japan
}

An investigation was carried out to monitor the escape and spread of oilseed rape (Brassica napus) transgenic plants and the introgression of transgenes to its closely related feral species in Japan. We screened a total of about 7500 feral B. napus, 300 B. rapa, and 5800 B. juncea seedlings from maternal plants in 143 locations at several ports, roadsides, and riverbanks. The presence of glufosinate-resistance or glyphosate-resistance transgenes in these seedlings was confirmed by means of herbicide treatments and also immunochemical and DNA analyses. B. napus plants with herbicide-resistant transgenic seeds were found at five of six major ports and along two of four sampled roadsides in the Kanto District. Transgenic oilseed rape plants have not been commercially cultivated in Japan, suggesting that the transgenes would probably have come from imported transgenic seeds that were spilled during transportation to oilseed processing facilities. No transgenes were detected in seeds collected from $B$. napus plants growing along riverbanks in the Kanto District or in seeds from closely related species ( $B$. rapa and $B$. juncea). To our knowledge, this is the first published example of feral, transgenic populations occurring in a nation where the transgenic crop has not been cultivated commercially.

Keywords: Brassica / establishment / glufosinate / glyphosate / herbicide / introgression / transgenic plant

\section{INTRODUCTION}

The ecological risks posed by transgenic plants (EFSA, 2004) are a matter of concern, as the numbers of these plants that are being cultivated, transported, and used for food processing and animal feed are increasing year by year (ISAAA, 2005). Most of the commercially grown transgenic plants are herbicide-, disease-, or pest-resistant crop plants, and are thought to have only limited potential ecological effects because they are not very invasive or persistent, and because the inserted traits would have little effect on the fitness of these plants in natural habitats (Crawley et al., 2001). However, some crop plants are able to survive outside cultivated areas and may become agricultural weeds or invasive species in natural habitats. For example, escaped plants of Brassica species such as B. napus L., B. rapa L., and B. juncea (L.) Czern. are often found growing outside cultivation at places such as roadsides or riverbanks in Japan and other countries (Crawley and Brown, 1995; OGTR, 2002; Pessel et al.,
2001). In addition, the possibility of transfer of the transgene by means of spontaneous crosses between transgenic plants and weedy or wild relatives, $e$. $g$. between transgenic B. napus and feral B. juncea in Japan, as well as changes in the fitness of the related species that received the transgene by introgression, should also be considered in risk assessment (Jørgensen et al., 1999; Messeguer, 2003). Therefore, it is necessary to monitor the presence of transgenic plants in natural habitats and, where they are present, to investigate their growth, propagation, and effects on other organisms, including the introgression of transgenes into wild relatives.

Transgenic oilseed rape (B. napus) plants with glufosinate-resistance or glyphosate-resistance transgenes were found at the port of Kashima in Japan's Kanto District in 2003 during an investigation by the Ministry of Agriculture, Forestry and Fisheries of Japan (results published through official government press releases in 2004). Since

\footnotetext{
* Corresponding author: hsaji@nies.go.jp
} 
a

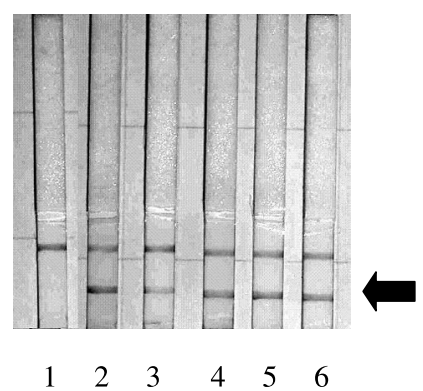

$\mathrm{C}$

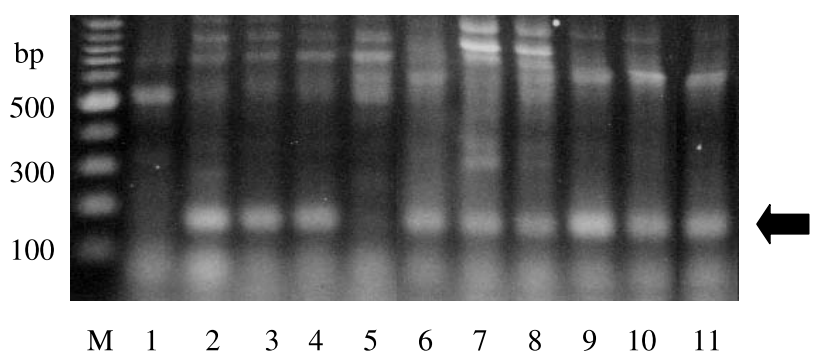

$\mathrm{b}$

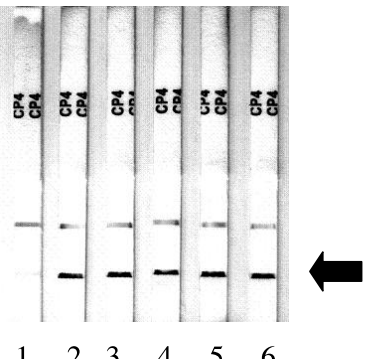

$\mathrm{d}$

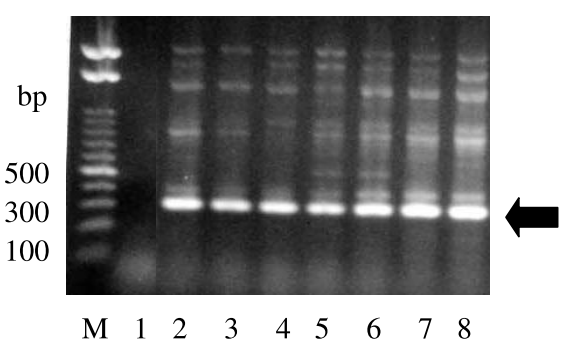

Figure 1. Representative results of the biochemical analyses that confirmed the presence of transgenes in the leaves of herbicideresistant Brassica napus seedlings grown from seeds collected from Japanese ports. (a) Results of immunochemical chromatography, showing the presence of PAT: lane 1, a glufosinate-sensitive control plant; lanes 2 to 6 , glufosinate-resistant plants from the port of Kashima. (b) Results of the immunochemical chromatography showing the presence of EPSPS: lane 1, a glyphosate-sensitive control plant; lanes 2 to 6, glyphosate-resistant plants from the port of Kashima. (c) Results of PCR showing the presence of the bar gene: M, molecular size marker; lanes 1 and 5, glufosinate-sensitive control plants; lane 2, a glufosinateresistant plant from the port of Nagoya; lanes 3 and 4, glufosinate-resistant plants from the port of Yokkaichi; lanes 6 to 11, glufosinate-resistant plants from the port of Kashima. (d) Results of PCR showing the presence of the cp4 epsps gene: lane 1, a glyphosate-sensitive control plant; lanes 2 to 6, glyphosate-resistant plants from the port of Nagoya; lane 7, a glyphosate-resistant plant from the port of Chiba; lane 8, a glyphosate-resistant plant from the port of Yokkaichi. Arrows indicate the position of herbicide-resistance enzymes or genes.

transgenic oilseed rape plants have not been commercially cultivated in Japan, these plants would have grown from seeds that were imported for use in production of rapeseed oil and spilled during transportation through the port. However, it was not clear whether this was the only case of such escaped seeds, and happened by chance, or whether transgenic plants were also growing elsewhere. The present study therefore investigated oilseed rape and closely related species growing at Kashima and several other ports, as well as specimens growing along roadsides and riverbanks, to look for the presence or absence of transgenes.

\section{RESULTS AND DISCUSSION}

Some oilseed rape seedlings grown from seeds collected from ports and roadsides survived the treatment with glufosinate or glyphosate, and all of these herbicideresistant seedlings were found to have the transgenes bar or cp4 epsps, respectively, and were also found to produce the products of these genes (Fig. 1). Transgenic offspring were detected at five of the six ports and at two of the four roadsides that we investigated (Tab. 1). Since these areas are either major ports of entry for oilseed rape imported mainly from Canada, or are located along the major roads leading from the port of Kashima (Fig. 2a), the transgenes would probably have been derived from imported seeds that were spilled during transportation. The possibility of other sources, such as the adventitious presence of transgenic plants in cultivated fields, appears to be low because the seeds for cultivation in Japanese fields are mainly imported from such countries as Italy, Australia and China where transgenic oilseed rape is not cultivated. It is not clear whether the transgenic seeds were produced 
Feral transgenic oilseed rape in Japan

Table 1. Numbers of locations where transgenic seeds were detected in each area of Japan.

\begin{tabular}{|c|c|c|c|c|}
\hline Area & Species & $\begin{array}{l}\text { No. of locations } \\
\text { where seeds } \\
\text { were collected }\end{array}$ & $\begin{array}{l}\text { No. of locations with } \\
\text { glufosinate-resistant } \\
\text { transgenic seeds }\end{array}$ & $\begin{array}{l}\text { No. of locations with } \\
\text { glyphosate-resistant } \\
\text { transgenic seeds }\end{array}$ \\
\hline \multicolumn{5}{|l|}{ Ports } \\
\hline \multirow{2}{*}{ Kashima } & B. napus & 14 & 2 & 2 \\
\hline & B. juncea & 2 & 0 & 0 \\
\hline Chiba & B. napus & 1 & 0 & 1 \\
\hline Yokohama & B. napus & 4 & 0 & 0 \\
\hline Nagoya & B. napus & 4 & 0 & 3 \\
\hline Yokkaichi & B. napus & 2 & 1 & 1 \\
\hline \multirow{3}{*}{ Kobe } & B. napus & 1 & 0 & 1 \\
\hline & B. rapa & 2 & 0 & 0 \\
\hline & B. juncea & 13 & 0 & 0 \\
\hline \multirow{3}{*}{ Total } & B. napus & 26 & 3 & 8 \\
\hline & B. rapa & 2 & $\mathbf{0}$ & $\mathbf{0}$ \\
\hline & B. juncea & 15 & $\mathbf{0}$ & $\mathbf{0}$ \\
\hline \multicolumn{5}{|l|}{ Roadsides in Kanto district } \\
\hline R50 & B. napus & 5 & 0 & 0 \\
\hline \multirow{2}{*}{ R51 } & B. napus & 15 & 2 & 8 \\
\hline & B. juncea & 1 & 0 & 0 \\
\hline \multirow{2}{*}{ R124 } & B. napus & 9 & 1 & 0 \\
\hline & B. juncea & 1 & 0 & 0 \\
\hline \multirow{2}{*}{$\mathrm{R} 125$} & B. napus & 9 & 0 & 0 \\
\hline & B. juncea & 5 & 0 & 0 \\
\hline \multirow{2}{*}{ Total } & B. napus & 38 & 3 & 8 \\
\hline & B. juncea & 7 & $\mathbf{0}$ & $\mathbf{0}$ \\
\hline \multicolumn{5}{|c|}{ Riverbanks in Kanto district } \\
\hline \multirow{2}{*}{ Yawara, Ibaraki } & B. napus & 3 & 0 & 0 \\
\hline & B. juncea & 2 & 0 & 0 \\
\hline Kawachi, Ibaraki & B. napus & 5 & 0 & 0 \\
\hline Toride, Ibaraki & B. juncea & 1 & 0 & 0 \\
\hline Tone, Ibaraki & B. juncea & 4 & 0 & 0 \\
\hline \multirow{2}{*}{ Kawagoe, Saitama } & B. napus & 2 & 0 & 0 \\
\hline & B. juncea & 2 & 0 & 0 \\
\hline \multirow{2}{*}{ Gyoda, Saitama } & B. napus & 1 & 0 & 0 \\
\hline & B. juncea & 13 & 0 & 0 \\
\hline \multirow{2}{*}{ Kuki, Saitama } & B. napus & 1 & 0 & 0 \\
\hline & B. juncea & 1 & 0 & 0 \\
\hline \multirow{2}{*}{ Shiraoka, Saitama } & B. napus & 1 & 0 & 0 \\
\hline & B. juncea & 2 & 0 & 0 \\
\hline \multirow{2}{*}{ Satte, Saitama } & B. napus & 3 & 0 & 0 \\
\hline & B. juncea & 5 & 0 & 0 \\
\hline \multirow{2}{*}{ Hasuda, Saitama } & B. napus & 3 & 0 & 0 \\
\hline & B. juncea & 4 & 0 & 0 \\
\hline Sakura, Chiba & B. juncea & 1 & 0 & 0 \\
\hline Nagareyama, Chiba & B. napus & 1 & 0 & 0 \\
\hline \multirow{2}{*}{ Total } & B. napus & 20 & $\mathbf{0}$ & $\mathbf{0}$ \\
\hline & B. juncea & 35 & $\mathbf{0}$ & $\mathbf{0}$ \\
\hline
\end{tabular}

There was no location that contained both glufosinate-resistant and glyphosate-resistant transgenic seeds. 

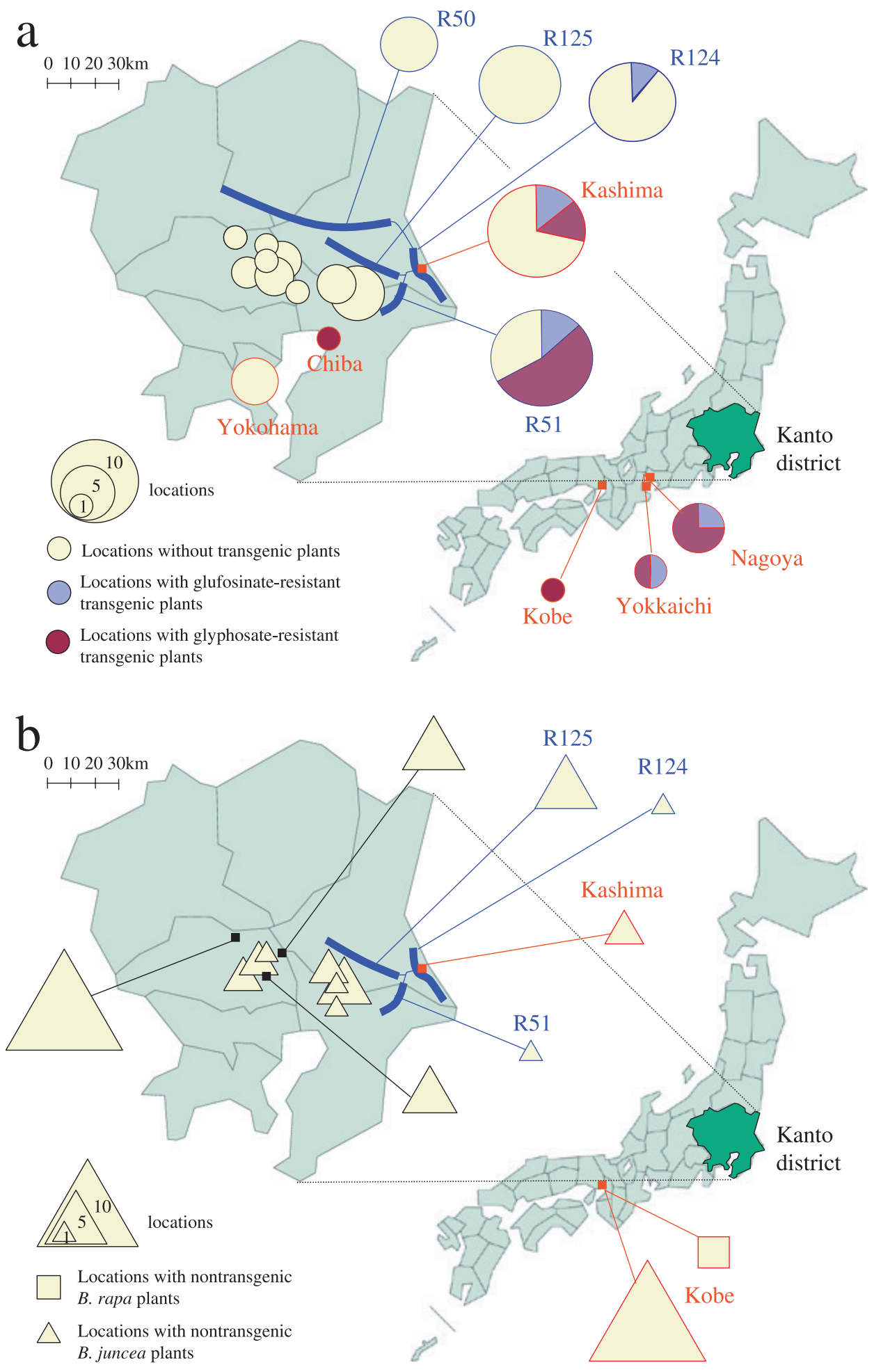

Figure 2. Survey of the distribution of Brassica plants with herbicideresistant transgenes around major Japanese ports as well as along roadsides and riverbanks in the Kanto District. (a) Results for $B$. napus plants. (b) Results for $B$. rapa and $B$. juncea plants. The area names in red and blue correspond to ports and roadsides, respectively, and circles, squares, and triangles without area names represent riverbanks. The sizes of the circles, squares, and triangles are proportional to the number of locations from which seeds of $B$. napus, $B$. rapa, and $B$. juncea were collected in each area, respectively. The sectors within the circles show the ratio of locations with glufosinateresistant transgenic plants, with glyphosate-resistant transgenic plants, and without transgenic plants in each area. (This figure is available in color in electronic form at www.edpsciences.org/ebr). 
by transgenic mother plants or formed on nontransgenic mother plants whose seeds were produced after crossing with transgenic pollen. Transgenic offspring were not detected in any seeds collected from riverbanks (Tab. 1), which were more or less distant from the predicted transportation routes (Fig. 2a).

The plants with transgenic seeds were restricted to $B$. napus, which is the only imported species in this genus that includes transgenes. No transgenes were detected in the collected seeds of B. rapa or B. juncea (Fig. 2b). It is unlikely that hemizygous plants were overlooked due to low expression of the transgenes, because herbicide resistance is a dominant trait. For example, when the bar gene was introgressed into $B$. rapa, it was expressed sufficiently strongly to make the host plant glufosinateresistant (Mikkelsen et al., 1996a). Furthermore, we also used immunochemical analyses to detect the presence of the products of the glyphosate-resistance transgene in a portion of the seeds collected at each location, and obtained results (data not shown) completely consistent with those obtained using the progeny.

Although we detected no transgene introgression into B. rapa or $B$. juncea in the present investigation, such introgression may occur in areas such as roadsides where plants of these species grow side by side, spontaneously or artificially, and hybridization or introgression has been reported to occur between $B$. napus and these species under natural conditions (Bing et al., 1996; Hansen et al., 2003; Jørgensen et al., 1996; Warwick et al., 2004). The fitness of the resulting hybrids or backcrossed plants is typically reduced in early generations; the $\mathrm{F}_{1}$ and $\mathrm{BC}_{1}$ generations usually exhibit reduced pollen fertility and seed production (Brown and Brown, 1996; Frello et al., 1995; Mikkelsen et al., 1996b). However, Snow et al. (1999) found that the magnitude of the fitness disadvantages in hybrid progeny of the cross between $B$. rapa and $B$. napus diminished with successive generations of backcrossing. They also showed that the benefits or costs associated with the transgenic glufosinate resistance were negligible in the absence of selection caused by herbicide application. However, the fitness of these transgenic progeny would be high where herbicide is used, resulting in their rapid propagation within these areas.

We are continuing our investigation to clarify whether transgenic oilseed rape plants will persist or propagate, and whether the transgenes will be introgressed into other related species at locations where transgenic seeds were detected during the present investigation. Although the results obtained in the present study are not highly quantitative, they suggest that transgenic oilseed rape plants are growing over a wide area in Japan. The detection of transgenic oilseed rape outside cultivation has already been reported in Canada (Warwick et al., 2003; 2004). However, to our knowledge, this is the first report that transgenic crop plants occur in feral populations in a nation where they have not been commercially cultivated. Our results suggest that transgenic plants may also be growing in other areas or countries where transgenic plants are not cultivated but their seeds are included in transported materials.

\section{MATERIALS AND METHODS}

\section{Sampling and analyses of herbicide resistance}

We collected a total of 100-200 seeds from May to July 2004 from 2-3 plants each of B. napus, B. rapa, and $B$. juncea found growing at each location. Since these are highly outcrossing, insect pollinated plants, sampling 100-200 seeds from a few maternal plants at each location allows sampling of a great many more paternal plants. We collected the seeds from 43 locations in major Japanese ports, 45 locations along roads leading away from Kashima port, and 55 locations along riverbanks in Japan's Kanto district where three of the major ports (Kashima, Chiba and Yokohama) are located (Tab. 1). A portion of the seeds (30 to 100 per location) was sown in a glasshouse and the seedlings were treated twice (at 1 to 2 weeks and at 2 to 3 weeks after sowing) with 0.23 g.L $\mathrm{L}^{-1}$ glufosinate (Basta, Hoechst Schering AgrEvo, Frankfurt, Germany). Another portion of the seeds of similar numbers was treated similarly with 1.0 g.L $\mathrm{L}^{-1}$ glyphosate (Roundup Highroad, Monsanto, Antwerp, Belgium). Seedlings that survived these herbicide treatments were analyzed as described below to detect the presence of transgenes. The remaining portion of the collected seeds (ca. 30 per location) was used in immunochemical chromatography (see below) to test for the presence of the products of the glyphosate-resistance transgene.

\section{Biochemical analyses}

For immunochemical chromatography, 50 to $100 \mu \mathrm{g}$ of leaf tissue or seeds were homogenized with a mortar and pestle in $10 \mathrm{ml}$.(g fresh weight $)^{-1}$ of distilled water, and the crude extracts were analyzed to detect the enzyme that confers resistance to glufosinate (PAT, phosphinothricin$\mathrm{N}$-acetyltransferase; Thompson et al., 1987) or the enzyme that confers resistance to glyphosate (EPSPS, 5-enolpyruvylshikimate-3-phosphate synthase; Comai et al., 1985), respectively, using the TraitChek LL Test Kit (Strategic Diagnostic Inc., Newark, DE, USA) and the 
Reveal kit (Neogen, Lansing, MI, USA). For DNA analyses, DNA was extracted from another leaf of the herbicide-resistant plant using the SDS-phenol method (Nakajima et al., 1988) and analyzed by means of PCR, using the primers 5'-TCGTCAACCACTACATCGAGACA-3' and 5'-GAAACCCACGTCATGCCAGTT-3' for the bar gene that encodes PAT, and using 5'-AAGAACTCCGCGTCAAGGAAAGCGA-3' and 5'-AGCCTTCGTATCGGAGAGTTCGAT-3' for the cp 4 epsps gene that encodes EPSPS. Amplifications using $100 \mathrm{ng}$ of extracted DNA were carried out in $20 \mu \mathrm{l}$ reaction mixtures containing $1 \times$ PCR buffer (Promega), $2.5 \mathrm{mM} \mathrm{MgCl}_{2}, 0.2 \mathrm{mM}$ of each dNTP, $1 \mu \mathrm{M}$ of each primer and $1.5 \mathrm{U}$ of rTaq polymerase, with 30 cycles of denaturation at $94^{\circ} \mathrm{C}$ for $1 \mathrm{~min}$, annealing for $2 \mathrm{~min}$ at $55 / 65^{\circ} \mathrm{C}$ for bar/cp 4 epsps, respectively and elongation at $72{ }^{\circ} \mathrm{C}$ for $3 \mathrm{~min}$. The PCR-amplified products were then subjected to an electrophoresis on $1.5 \%$-agarose gel. The DNA bands of appropriate sizes were recovered from the gel and their nucleotide sequences were determined using a DNA sequencer (ABI3700, Applied Biosystems, Foster City, CA, USA) to confirm that these products corresponded to fragments of the respective genes.

\section{ACKNOWLEDGMENTS}

We thank Naoto Yasuda of the Ministry of Environment of Japan for valuable discussions and critical reading of the manuscript. This project was funded by the Ministry of Environment of Japan.

Received August 24, 2005; accepted February 6, 2006.

\section{REFERENCES}

Bing DJ, Downey RK, Rakow GFW (1996) Hybridizations among Brassica napus, B. rapa and B. juncea and their two weedy relatives $B$. nigra and Sinapis arvensis under open pollination conditions in the field. Plant Breed. 115: 470-473

Brown J, Brown AP (1996) Gene transfer between canola (Brassica napus L. and B. campestris L.) and related weed species. Annal. Appl. Biol. 129: 513-522

Comai L, Facciotti D, Hiatt WR, Thompson G, Rose RE, Stalker DM (1985) Expression in plants of a mutant aroA gene from Salmonella typhimurium confers tolerance to glyphosate. Nature 317: 741-744

Crawley MJ, Brown SL (1995) Seed limitation and the dynamics of feral oilseed rape on the M25 motorway. Proc. Royal Soc. London B 259: 49-54

Crawley MJ, Brown SL, Hails RS, Kohn DD, Rees M (2001) Transgenic crops in natural habitats. Nature 409: 682-683

EFSA (2004) Guidance document of the scientific panel on genetically modified organisms for the risk assessment of genetically modified plants and derived food and feed. http:// www.efsa.eu.int/science/gmo/gmo_guidance/660_en.html

Frello S, Hansen KR, Jensen J, Jørgensen RB (1995) Inheritance of rapeseed (Brassica napus)-specific RAPD markers and a transgene in the cross $B$. juncea $\times(B$. juncea $\times$ B. napus). Theor. Appl. Genet. 91: 236-241

Hansen LB, Siegismund HR, Jørgensen RB (2003) Progressive introgression between Brassica napus (oilseed rape) and B. rapa. Heredity 91: 276-283

ISAAA (2005) Preview: Global Status of Commercialized Biotech/GM Crops: 2004. http://www.isaaa.org/

Jørgensen RB, Andersen B, Landbo L, Mikkelsen TR (1996) Spontaneous hybridization between oilseed rape (Brassica napus) and weedy relatives. Acta Horticul. 407: 193-197

Jørgensen RB, Andersen B, Snow A, Hauser TP (1999) Ecological risks of growing genetically modified crops. Plant Biotechnol. 16: 69-71

Messeguer J (2003) Gene flow assessment in transgenic plants. Plant Cell Tissue Organ Culture 73: 201-212

Mikkelsen TR, Andersen B, Jørgensen RB (1996a) The risk of crop transgene spread. Nature 380: 31

Mikkelsen TR, Jensen J, Jørgensen RB (1996b) Inheritance of oilseed rape (Brassica napus) RAPD markers in a backcross progeny with Brassica campestris. Theor. Appl. Genet. 92: 492-497

Nakajima N, Kakagawa N, Imaseki H (1988) Molecular size of wound-induced 1-aminocyclopropane-1-carboxylate synthase from Cucurbita maxima Duch. and change of translatable mRNA of the enzyme after wounding. Plant Cell Physiol. 29: 989-998

OGTR (2002) The biology and ecology of canola (Brassica napus). http://www.ogtr.gov.au/pdf/ir/brassica.pdf

Pessel FD, Lecomte J, Emeriau V, Krouti M, Messéan A, Gouyon PH (2001) Persistence of oilseed rape (Brassica napus L.) outside of cultivated fields. Theor. Appl. Genet. 102: $841-846$

Snow AA, Andersen B, Jørgensen RB (1999) Costs of transgenic herbicide resistance introgressed from Brassica napus into weedy B. rapa. Mol. Ecol. 8: 605-615

Thompson CJ, Movva NR, Tizard R, Crameri R, Davies JE, Lauwereys M, Botterman J (1987) Characterization of the herbicide-resistance gene bar from Streptomyces hygroscopicus. EMBO J. 6: 2519-2523

Warwick SI, Simard MJ, Légère A, Beckie HJ, Braun L, Zhu B, Mason P, Séguin-Swartz G, Stewart CN (2003) Hybridization between transgenic Brassica napus L. and its wild relatives: Brassica rapa L., Raphanus raphanistrum L., Sinapis arvensis L., and Erucastrum gallicum (Willd.) O.E. Schulz. Theor. Appl. Genet. 107: 528-539

Warwick SI, Beckie HJ, Simard MJ, Légère A, Nair H, Séguin-Swartz G (2004) Environmental and agronomic consequences of herbicide-resistant (HR) canola in Canada. In Den Nijs HCM, Bartsch D, Sweet J, eds, Introgression from Genetically Modified Plants into Wild Relatives, CABI, pp 323-337 